\title{
PRODUCTION OF ARTHRITIS IN THE RABBIT BY THE LOCAL INJECTION OF THE MUCOPOLYSACCHARIDE CARAGHEENIN
}

\author{
BY \\ D. L. GARDNER \\ Department of Pathology, University of Edinburgh, \\ and Rheumatic Research Unit, Northern General Hospital, Edinburgh
}

In the laboratory study of rheumatoid arthritis the need has long been felt for a convenient animal replica of this disease. Very many techniques have been used during the past century for this purpose; they have recently been reviewed (Gardner, 1960). Forms of experimental arthritis have been studied in the monkey, horse, sheep, goat, pig, dog, rabbit, guinea-pig, rat, mouse, and chick-embryo, but none has provided a universally acceptable model. In the hope that an easily reproducible form of laboratory arthritis might lead to an advance in our understanding of the pathogenesis of rheumatoid arthritis, experiments have been made with the sulphated mucopolysaccharide caragheenin. This substance, obtained from the Irish moss Chondrus crispus, or from Scottish seaweed, has previously been used in the study of collagen fibre formation because of its remarkable capacity to stimulate local inflammation dominated by intense macrophage aggregation and by fibroblastic proliferation (Jackson, 1956a, b; Williams, 1957).

In the experimental study of arthritis, caragheenin appears to offer certain advantages as a stimulating material. Owing to its chemical structure, its position in the injected tissues is readily determined by the periodic acid-Schiff reaction. It is easily dissolved in isotonic saline, forming a gel at room temperature but becoming less viscous on warming. Sterilization can be effected by boiling without impairing the capacity of the material to cause inflammation, while the presence of sulphate groups on the molecule suggests that future studies with labelled caragheenin may be possible.

\section{Material}

A supply of a crude extract of caragheenin was obtained through the courtesy of the director of the Seaweed
Research Station at Musselburgh. Partial purification of the crude extract by dialysis did not alter the inflammatory reaction produced on injection. For use, the caragheenin powder was made up in isotonic normal saline and sterilized by boiling.

English rabbits of both sexes were used; the animals were mature and of good nutritional status, and were maintained on a diet containing all known essential factors.

Guinea-pigs were of a laboratory-bred strain. They were large, mature, and well-fed. Their diet contained all known essential nutritional factors.

For comparison with animal material, joints from twenty cases of rheumatoid arthritis were selected. These cases formed part of a series in which a post mortem examination had been conducted personally.

\section{Methods}

The injection of caragheenin was undertaken in three ways:

(1) Intradermally, as a dilute solution, without anaesthesia, into the skin of guinea-pigs.

(2) Under ether anaesthesia, into the joints of guinea-pigs.

(3) Under pentobarbitone anaesthesia, into the joints of rabbits.

Material for biopsy was collected under ether anaesthesia. Animals were killed by the injection of pentobarbitone.

Tissue samples were placed in neutral formol saline immediately after biopsy or death. Bone was decalcified in a formic acid-sodium citrate mixture. Paraffinembedded sections were cut at 4-8 $\mu$, and were stained with haematoxylin and eosin, by the periodic acid-Schiff reaction, and by Masson's trichrome method.

\section{Procedure}

The experiment was conducted in three parts:

(1) The optimal strength of a solution of caragheenin required to give a readily detectable inflammatory re- 
sponse was determined by a series of injections into guinea-pig skin.

$0.1 \mathrm{ml}$. of each of the following concentrations of the caragheenin solution were injected into the shaved dorsal skin of a guinea-pig: $0 \cdot 25$, $0 \cdot 5,1$, and 2 per cent. A biopsy of each lesion was performed 36 hours later.

(2) A general assessment of the type of reaction to be expected following intra-articular injection, and the size and frequency of injections required to give a brisk articular response, were determined by the injection of amounts of the solution of optimal concentration into the joints of eight guinea-pigs.

Single injections of $0.1 \mathrm{ml}$. of a 1 per cent. solution of caragheenin were made into the large limb joints of guinea-pigs at the following intervals before biopsy: 1 month, 2 weeks, 1 week, 3 days, 1 day, and 6 hours.

Repeated injections of $0.1 \mathrm{ml}$. of the 1 per cent. solution were made at the following intervals:

(i) Eleven injections at 3-day intervals

(ii) Six injections at 7-day intervals

(iii) Four injections at 7-day intervals

(iv) Four injections at 14-day intervals

(v) Three injections at 14-day intervals

(vi) Three injections at 21-day intervals

(3) A more detailed study was made of the articular response to the injection at optimal intervals of moderate to large amounts of the solution of optimal strength, using for this purpose eleven rabbits.
The amounts of caragheenin injected into the principal limb joints at stated intervals are shown in the Table.

After these series of injections were completed, the animals were killed and the tissues examined histo- $\vec{F}$ logically.

\section{Results}

(1) Response of Guinea-pig Skin.-An optimal $\stackrel{\varnothing}{\overparen{D}}$ response was given by the injection of $0.1 \mathrm{ml}$. of the 1 per cent. solution. An intense histiocytic reaction, with smaller numbers of polymorpho-? nuclear leucocytes, was concentrated within the $\overrightarrow{\vec{\omega}}$ deeper layers of the dermis and the subcutaneous of tissues.

(2) Response of Guinea-pig Joints.-After 6 hours $\overrightarrow{0}$ a single injection of $0.1 \mathrm{ml}$. of the 1 per cent. solution $\dot{\dot{\omega}}$ produced an intense polymorphonuclear leucocytic o inflammatory cell reaction. After 24 hours and 0 after 3 days the cellular characteristics of the inflammatory infiltrate changed to include a progressively $\vec{\nabla}$ larger proportion of histiocytes and later fibro- $\mathbb{\mathbb { D }}$ blasts. After 1 month no detectable abnormality remained.

Intra-articular injection of $0 \cdot 1$ per cent. and of 0.5 per cent. solutions produced slight response $\vec{\bullet}$ only. A greatly exaggerated reaction was detecte after the 1 per cent. solution and this strength was. accepted as optimal. The viscosity of the 2 per cent. solution, which produced only a little more

TABLE

ARTICULAR RESPONSE IN TEN RABBITS

\begin{tabular}{|c|c|c|c|c|c|}
\hline Series & $\begin{array}{c}\text { Rabbit } \\
\text { No.* }\end{array}$ & $\begin{array}{l}\text { Dose } \\
\text { (ml.) }\end{array}$ & $\begin{array}{l}\text { Frequency } \\
\text { (per week) }\end{array}$ & $\begin{array}{l}\text { Duration } \\
\text { (wks) }\end{array}$ & $\begin{array}{l}\text { No. of } \\
\text { Injections }\end{array}$ \\
\hline \multirow{3}{*}{ Experimental } & $\begin{array}{l}1 \\
2\end{array}$ & $\begin{array}{l}0.5 \mathrm{ml} \text {. of } 1 \text { per cent. solu- } \\
\text { tion rising to } 1 \mathrm{ml} \text {. of } 1 \text { per } \\
\text { cent. solution }\end{array}$ & Once & $\begin{array}{r}6 \\
10\end{array}$ & $\begin{array}{r}7 \\
11\end{array}$ \\
\hline & $\begin{array}{l}3 \\
4 \\
5\end{array}$ & $1 \mathrm{ml}$. of 1 per cent. solution & Twice & $\begin{array}{l}3 \\
3 \\
3\end{array}$ & $\begin{array}{l}6 \\
6 \\
6\end{array}$ \\
\hline & $\begin{array}{r}8 \\
9 \\
10\end{array}$ & $\begin{array}{l}\text { Amounts of } 1 \text { per cent. } \\
\text { solution increasing from } 1 \\
\text { to } 5 \mathrm{ml} \text {. per joint }\end{array}$ & Twice & $\begin{array}{l}4 \cdot 5 \\
4 \\
3\end{array}$ & $\begin{array}{l}9 \\
8 \\
6\end{array}$ \\
\hline \multirow{2}{*}{ Control } & 6 & $\begin{array}{l}\text { Increasing amounts intra- } \\
\text { venously to a total of } 19 \mathrm{ml} \text {. }\end{array}$ & Once & 11 & 11 \\
\hline & 7 & $\begin{array}{l}0 \cdot 5-1 \mathrm{ml} \text {. normal saline } \\
\text { intra-articularly }\end{array}$ & Once & 10 & 10 \\
\hline
\end{tabular}

* Rabbit No. 11 died during the course of the experiment 
inflammatory response, became so great that much difficulty was experienced in handling the material before injection, even with prior warming of the mixture and of the syringe.

(3) Response of Rabbit Joints. - A certain variability was observed, possibly related to the varying difficulty experienced in injecting the caragheenin solution. Generally, to produce a prolonged arthritic response, it was necessary to inject caragheenin at intervals of not more than 3 to 7 days; for this purpose the 1 per cent. solution was most convenient. With this procedure examination of the joints after intervals of 6 to 10 weeks revealed inflammatory proliferation of the synovial villi (Figs 1 and 2), with increased cellularity, and a marginal attachment of synovia to the superficial parts of the articular cartilages (Figs 3 and 4). Progressive replacement fibrosis of articular cartilage (Figs 5 and 6) by cellular connective tissue in continuity with that of the hypercellular synovial fringes commonly resulted in the formation of pannus, a change apparently analogous with the marginal "invasion" of articular cartilage seen in rheumatoid arthritis. The cellular reaction differed from that seen in rheumatoid arthritis, however, in that the predominant cell type present was the

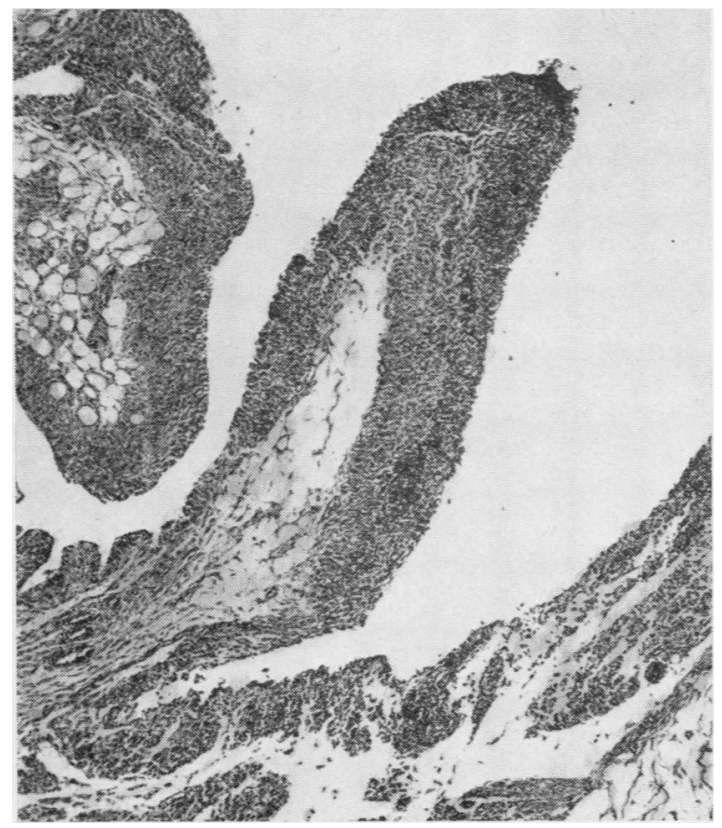

Fig. 1.-Rabbit 1, seven injections at weekly intervals. Widespread lymphocytic reaction in hyperplastic synovial villi. Haematoxylin and eosin $\times 60$. lymphocyte and not the plasma cell (Figs 7 and 8). Nevertheless, the infiltrate was sometimes perivascular in distribution (Figs 9 and 10) and was accompanied by periarticular fibrosis (Figs 11 and 12). In the superficial margins of occasional hyperplastic synovial villi were accumulations of material staining positively for fibrin (Figs 13 and 14), but fibrinoid change was not an invariable characteristic of the reaction. Osteoclastic bone reabsorption was an occasional finding (Figs 15 and 16).

When a comparison was made between the animal joints and those from patients dying with rheumatoid arthritis, it proved possible, by the exercise of considerable selection, to find areas in both animal and human tissue which were morphologically very similar. Since the histological characteristics of the joints in rheumatoid arthritis are not individually specific, there was no justification for deducing that the rabbit arthritis produced by caragheenin offered more than a crude replica of the human disease. Nevertheless, it was felt that the model offered certain practical advantages which might make it acceptable as a basis for future use, and in particular for the laboratory study of iron metabolism in animals with a chronic arthritis (Richmond, Gardner, Roy, and Duthie, 1956; Richmond, Roy, Gardner, Alexander, and Duthie, 1958.

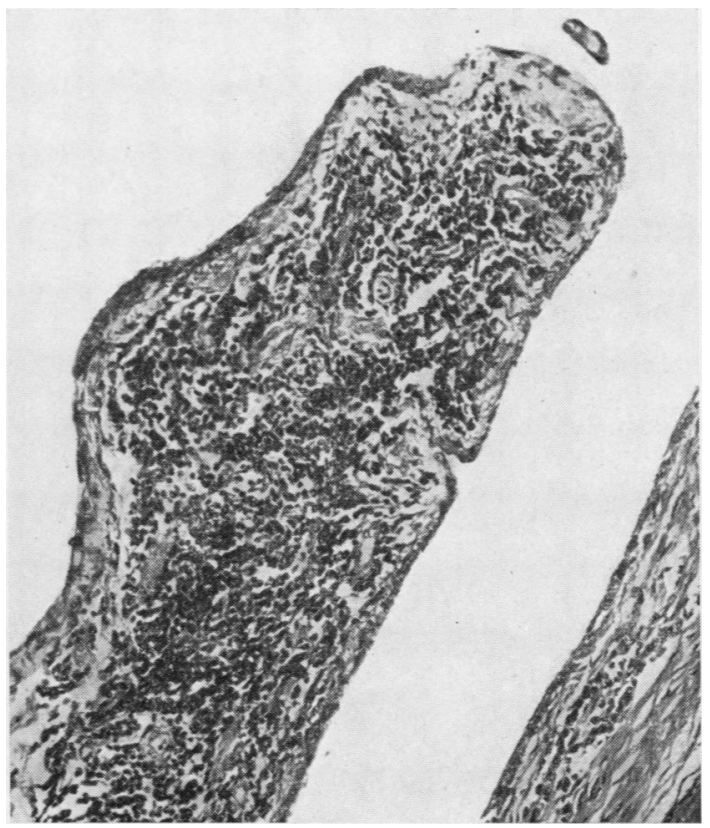

Fig. 2.-For comparison with Fig. 1. Synovial villi from an interphalangeal joint in a case of long-standing rheumatoid arthritis. Haematoxylin and eosin $\times 140$. 
Fig. 3.-Rabbit 2, seven injections at weekly intervals. Mononuclear cells, fibroblasts, and cell debris form an irregular pannus in continuity with the superficial layer of articular cartilage.

$$
\text { Haematoxylin and eosin } \times 350 \text {. }
$$

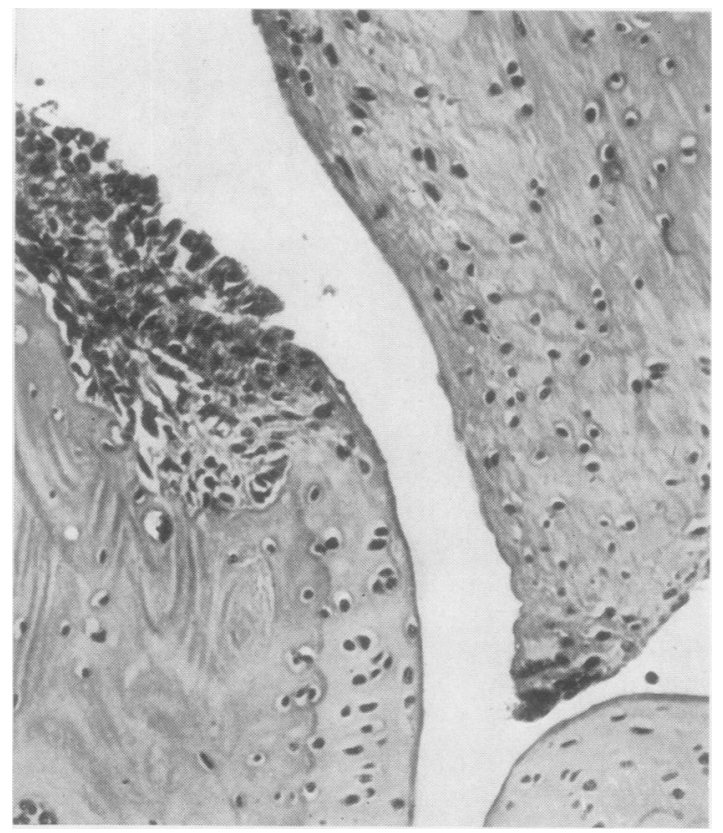

Fig. 5.-Rabbit 5, injections twice weekly for 3 weeks. Margin of articular cartilage undergoing replacement by lymphocytes and histiocytes.

Haematoxylin and eosin $\times 200$.

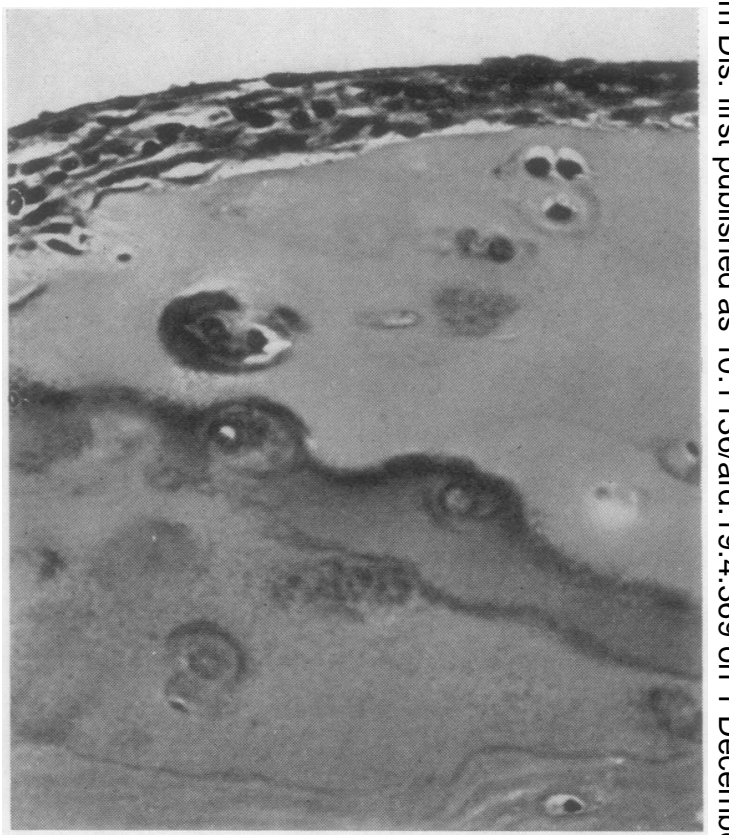

Fig. 4.-For comparison with Fig. 3. Marginal replacement fibrosis of articular cartilage from an interphalangeal joint in a case of long $\overrightarrow{0}$ standing rheumatoid arthritis. Haematoxylin and eosin $\times 350$.

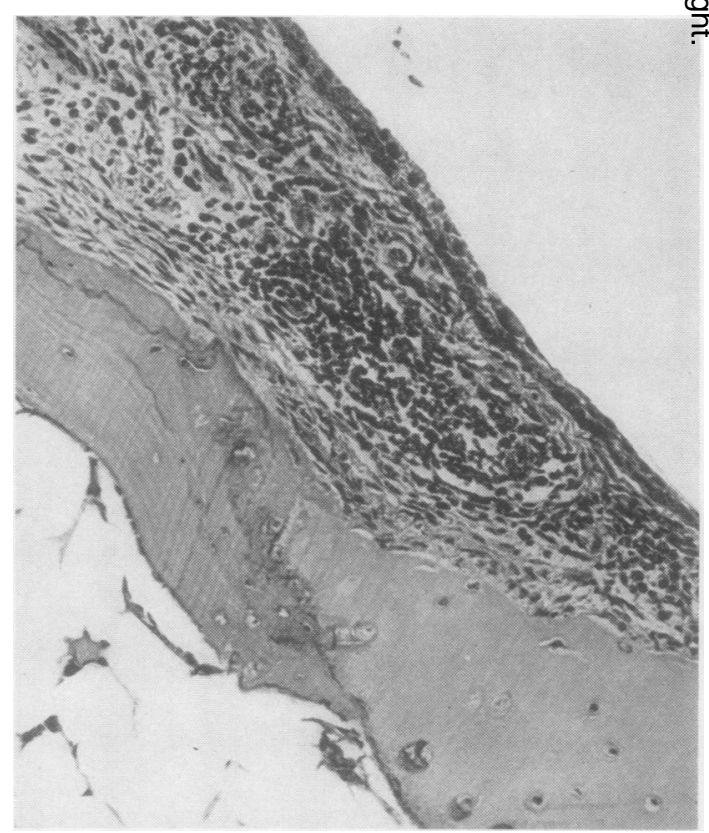
응 용

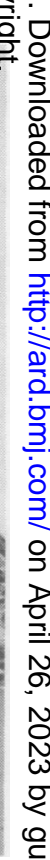
Fig. 6.-For comparison with Fig. 5. Replacement of border of $\stackrel{\mathbb{D}}{+}$
articular catilage of finger joint in a case of old active rheumatoid arthritis.

Haematoxylin and eosin $\times 200$. 


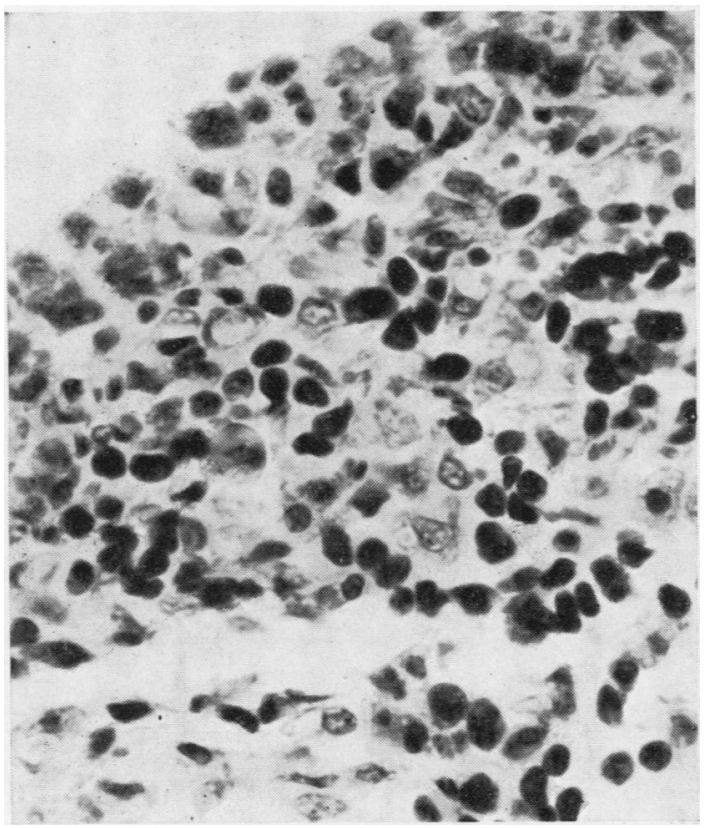

Fig. 7.-The cellular response in arthritis induced by caragheenin is predominantly histiocytic. Haematoxylin and eosin $\times 640$.

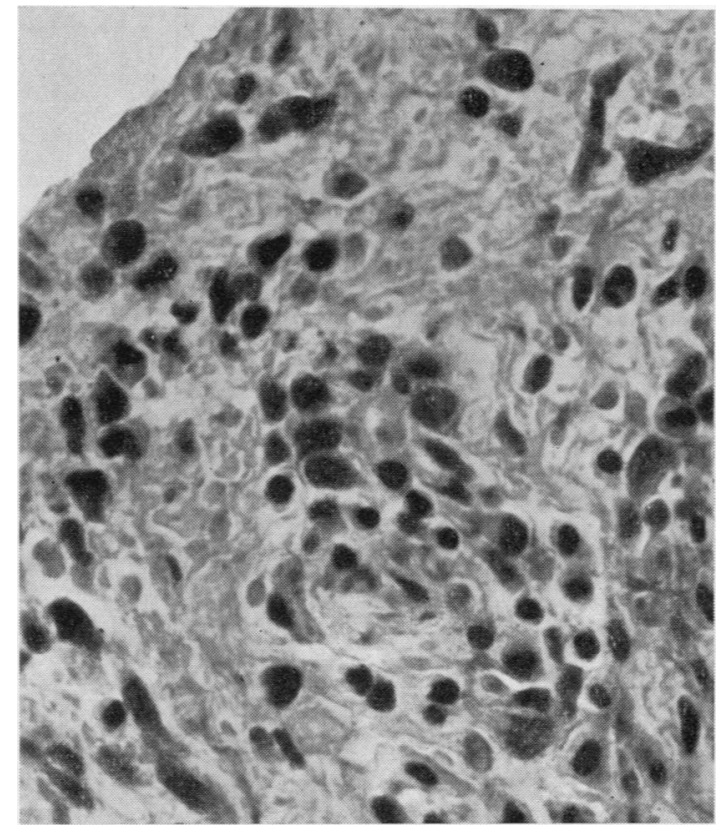

Fig. 8.-In contrast with Fig. 7. The predominance of plasma cells is pathognomonic of active rheumatoid arthritis.

Haematoxylin and eosin $\times 650$.

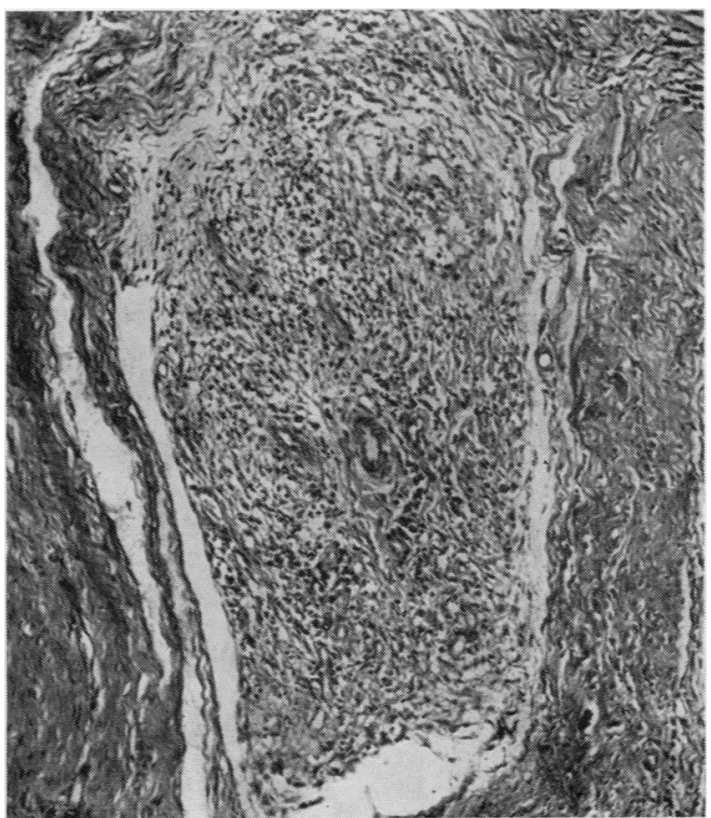

Fig. 10.-For comparison with Fig. 9. Perivascular fibrosis and inflammatory cells at margin of interphalangeal joint in active rheumatoid arthritis.

Haematoxylin and eosin $\times 100$. 


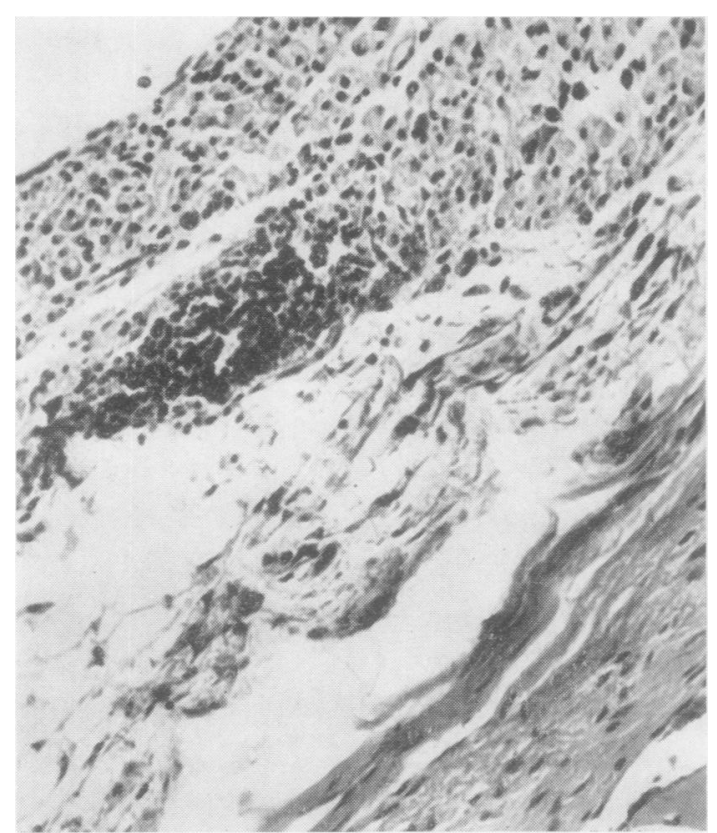

Fig. 11.-Rabbit 5. Lymphocytic foci within the para-articular soft tissues.

Haematoxylin and eosin $\times 200$.

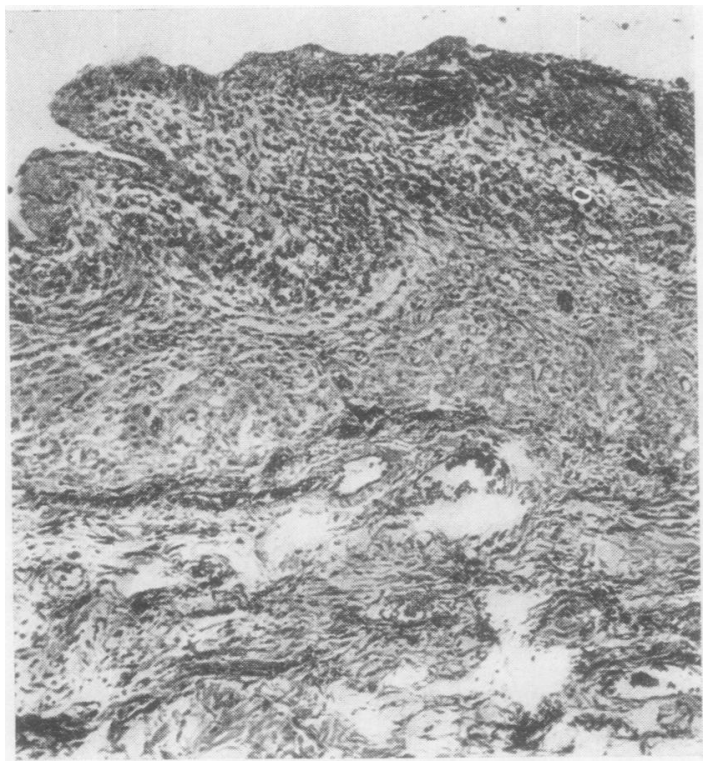

Fig. 13.-Rabbit 7, left fore-limb. Fibrin deposited superficially on hyperplastic cellular synovial tissue. Haematoxylin and eosin $\times 95$.

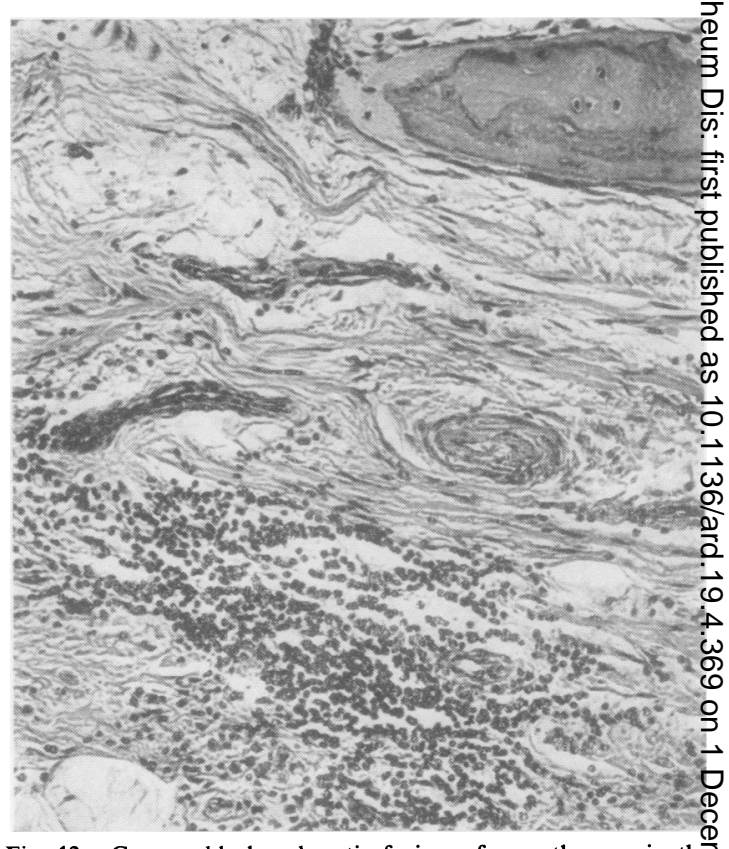

Fig. 12.-Comparable lymphocytic foci are frequently seen in the soft tissues bounding involved metacarpophalangeal joints i rheumatoid arthritis.

Haematoxylin and eosin $\times 200$.

융

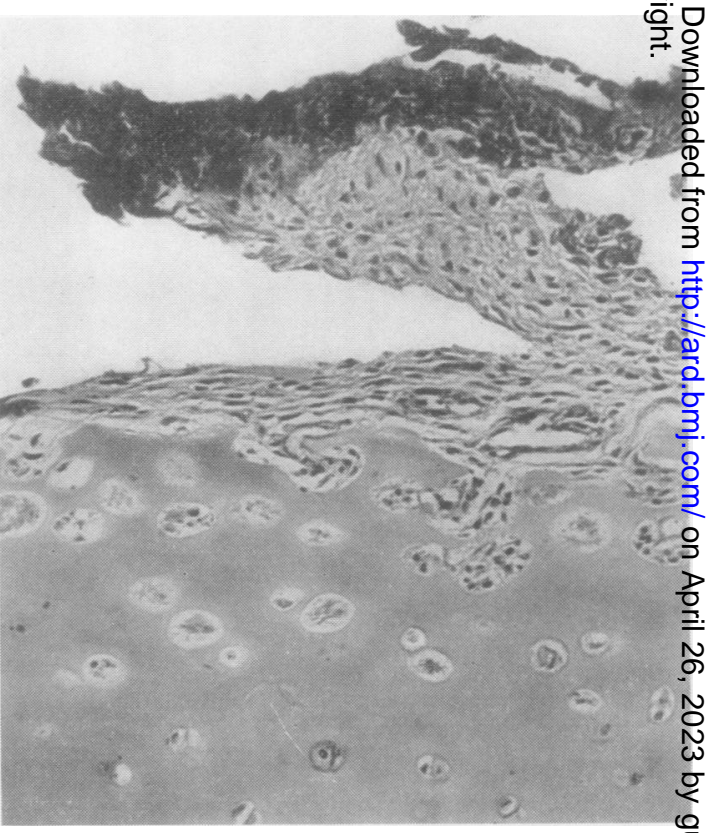

Fig. 14.-For comparison with Fig. 13. Fibrinoid in margin क्षे synovial villus in metacarpophalangeal joint in a case of active longe standing rheumatoid arthritis. Haematoxylin and eosin $\times 200$. 


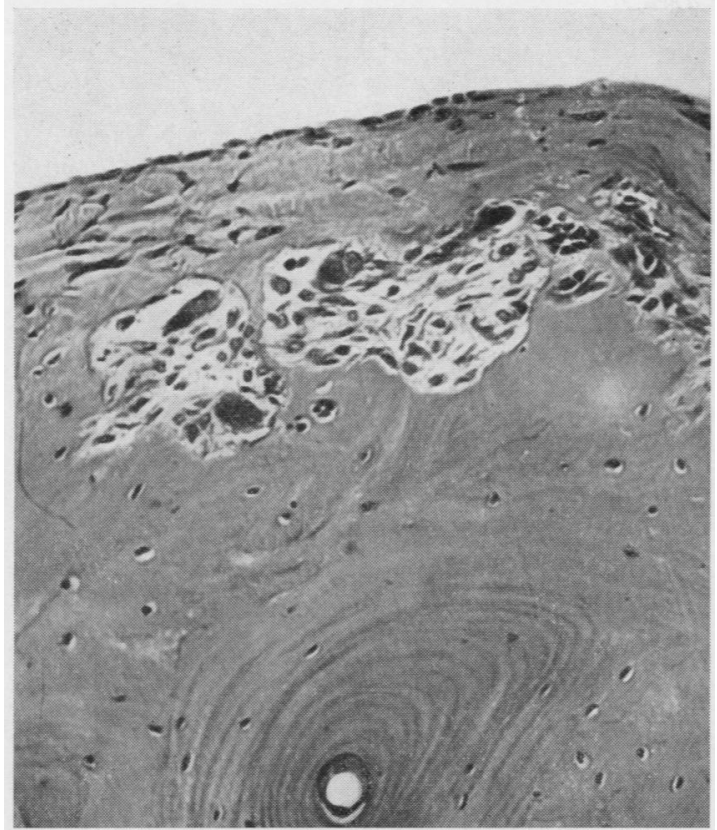

Fig. 15.-Rabbit 6. Osteoclastic bone reabsorption is frequent at the margins of involved joints in arthritis caused by caragheenin. Haematoxylin and eosin $\times 200$.

\section{Discussion}

The experiment described in the present paper has shown that the large limb joints of guinea-pigs and of rabbits respond to the injection of a sterile solution of the mucopolysaccharide caragheenin in isotonic saline by the production of an inflammatory response, which can be perpetuated by repetitive injection, and which results after 6 to 10 weeks in the appearance of histological changes which individually may resemble closely those found in rheumatoid arthritis in the human. Very many alternative methods for the production of arthritis in laboratory animals have previously been described, but the present method is both simple, reproducible, and free from some of the uncontrolled incidental factors which have plagued so many of the methods described in the literature. Caragheenin is more readily obtained, more easily handled, and less disturbed by environmental changes than the mucopolysaccharides used by Jones and Carter (1954), Jones, Carter, and Rankin (1954), Jones and Carter (1957a, b), and Jones and Mayne (1958). Its reactivity appears to depend entirely upon a local stimulus to inflammation, and it is not known to be antigenic. Repeated injections maintain but do not exaggerate local responses, and repeated systemic

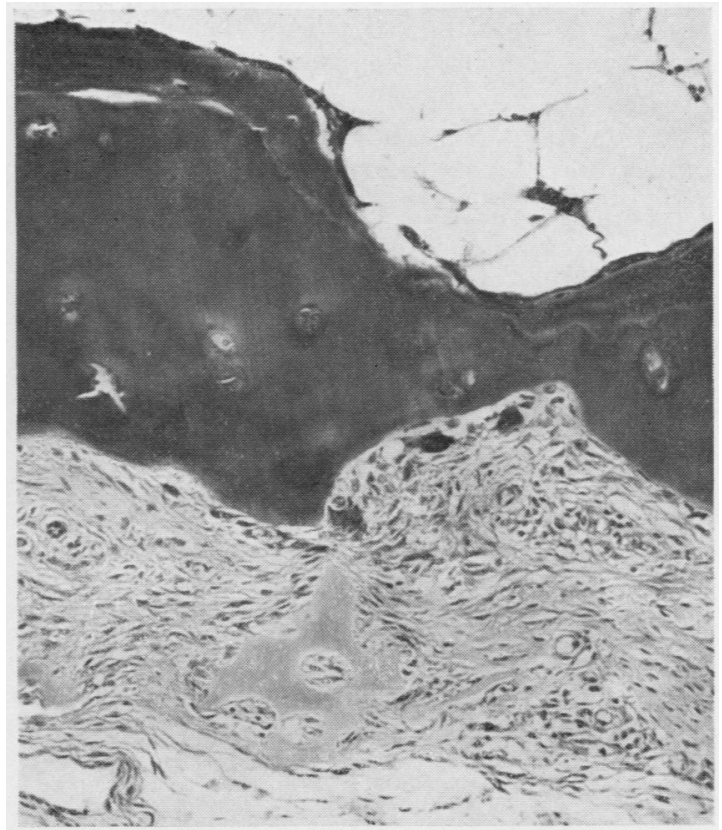

Fig. 16.-For comparison with Fig. 15. Similar appearances are found in active chronic rheumatoid arthritis. Haematoxylin and eosin $\times 200$.

administration has caused no detectable change in the lungs, liver, and other viscera.

Whether future experiments will show that it is possible to reproduce in animals an arthritis comparable in every way to rheumatoid arthritis in the human is uncertain. It appears from the large amount of work performed on small rodents that these species are not likely to yield the answer to this question. The present author is among those who believe that it may prove necessary to turn to the primates before a complete animal replica of the human disease is found; this approach to the problem will be both arduous and costly.

\section{Summary}

(1) The highly sulphated mucopolysaccharide caragheenin extracted from Irish moss or from Scottish seaweed has been uscd to induce an articular inflammatory reaction in guinea-pigs and in rabbits. Experiment has shown that an optimal response is obtained when a 1 per cent. solution in sterile isotonic saline is injected at intervals of not more than 7 days for at least 6 weeks.

(2) Under these circumstances an arthritis may be produced the individual histological characteristics of which may closely resemble those of selected 
cases of rheumatoid arthritis in the human. No claim can legitimately be made to have reproduced any particular form of human arthritis, but the procedure offers certain advantages for the future study of experimental arthritis.

The constant advice and encouragement of Dr. J. J. R. Duthie are gratefully acknowledged.

During the period in which this work was undertaken the Rheumatic Research Unit was in receipt of grants from the Nuffield Foundation, from the Medical Research Council, and from Boots Pure Drug Company.

\section{REFERENCES}

Gardner, D. L. (1960). Ann. rheum. Dis. 19, 297.

Jackson, D. S. (1956a). Biochem. J., 62, 25P

(1956b). Ibid., 64, 8P.

Jones, R. S., and Carter, Y. (1954). Arch. Path., 58, 613.

Jones, R. S., and Carter, Y. (1954)

(1957a). Ibid., 63, 472 .

- (1957b). Ibid., 63, 484.

and Mayne, Y. C. (1958). Arch. Path., 65, 247.

Richmond, J., Gardner, D. L., Roy, L. M. H., and Duthie, J. J. R. (1956). Ann. rheum. Dis., 15, 217.

Roy, L. M. H., Gardner, D. L., Alexander, W. R. M., and. Duthie, J. J. R. (1958). Ibid., 17, 406.

Williams, G. (1957). J. Path. Bact., 73, 557.

Production d'arthrite chez le lapin par injection locale de mucopolysaccharide caragheenin

RÉSUMÉ

(1) Le mucopolysaccharide très sulfaté caragheenin, extrait de l'algue marine irlandaise ou écossaise (Irish moss ou Scottish seaweed) fut employé pour induire uneD réaction inflammatoire articulaire chez des cobayes et5 des lapins. On détermina expérimentalement qu'une réponse optimum s'obtient lorsqu'on injecte à des intervalles de 3 à 7 hours, pendant au moins 6 semaines, une solution à 1 pour cent en l'eau physiologique stérile

(2) En ces circonstances on peut produire une arthrite dont les traits histologiques individuels ressemblent de près ceux des cas selectionnés d'arthrite rhumatismaleo humaine. On ne peut pas prétendre légitimément qu'onō ait reproduit une forme particulière d'arthrite humaine $\vec{\Phi}$ mais le procédé offre certains avantages pour l'étudę future de l'arthrite expérimentale.

Producción de artritis en el conejo por inyección local de mucopolisacarido caragheenin

\section{SUMARIO}

(1) El altamente sulfatado mucopolisacarido cara gheenin extraido del alga marina irlandesa o escocesa(Irish moss o Scottish seaweed) fué usado para induciro una reacción inflamatoria articular en cobayos y conejos ${ }^{-}$ Experimentalmente se determinó que la respuesta óptima se presenta cuando se inyecta con intervalos noe superiores a 3-7 días por no menos de 6 semanas una은 solución al 1 por ciento en suero salino isotónico esteril.

(2) En estas circunstancias puede ser producida una artritis de características histológicas individuales cono una semejanza cercana a casos seleccionados de artritisß్ర reumatoide en el hombre. No es posible afirmar ques se haya reproducido una forma particular de artritiso humana, pero el procedimiento ofrece ciertas ventajas para el futuro estudio de la artritis experimental. 